\title{
Når tallene trenger behandling
}

\author{
Akkurat som pasienter utsetter besøk hos lege i håp om at det ordner seg selv, er det ofte først når tallenes \\ smerte hindrer det daglige virke at forskere oppsøker statistikere for å få råd. Statistisk veiledning i medisinske \\ forskningsprosjekter er et eget fagfelt og forutsetter gode kunnskaper i statistikk, matematikk og forsknings- \\ metode og interesse for medisin og biologi. Så hva kan statistikere bidra med i forskningsprosjekter?
}

Are Hugo Pripp

apripp@ous-hf.no

Mange med utdanning i forsøksmetodikk og statistikk vil bidra med rådgivning i sitt yrkesliv. Betydningen av statistisk veiledning innenfor medisinsk forskning er godt dokumentert (1). Storparten av den daglige kliniske praksisen er likevel ikke avhengig av profesjonelle statistikere. Derfor er det ofte opp til statistikerne selv å overbevise om at de kan bidra i medisinsk forskning, enten med sine metoder eller med konsultasjon og veiledning. Å vektlegge gale og ikke-relevante problemstillinger eller å kommunisere slik at andre ikke ser nytten av deres bidrag, medfører at statistikerne kan miste sin kredibilitet og sin mulighet til å bidra i et medisinsk fagmiljø (2).

Statistisk veiledning, herunder hjelp i planleggingsfasen og valg av epidemiologisk studiedesign, omfatter mange aspekter utover kunnskap og bruk av statistiske metoder. Rent konkret skal hensikt og problemstilling reformuleres til statistiske estimater og metoder. Ifølge Kenett \& Thyregod (3) involverer dette momenter både før og etter de spesifikke statistiske analysene. De mener at en typisk konsultasjon innebærer fem steg: å identifisere problemstilling, å bearbeide rådata til analysen, å utføre dataanalyse ved hjelp av statistiske metoder, å beskrive og å presentere konklusjoner, konsekvenser og anbefalinger.

Et vanlig råd er å involvere statistiker tidlig i prosessen, men akkurat som man utsetter besøk hos lege i håp om at det ordner seg selv, bør statistikere som arbeider med rådgivning, ha forståelse for at de oppsøkes først når tallenes smerte hindrer det daglige virke. Kauermann \& Weihs (4) sammenlikner nettopp det å oppsøke en statistisk veileder med å besøke en lege eller en advokat - det er nødvendig, men ikke nødvendigvis lystbetont. Da er det en utfordring å få kontakt med dem som ikke oppsøker en fagperson av seg selv.

\section{Hva forventes ved statistisk konsultasjon?}

Den direkte veiledningen i et forskningsprosjekt er en opplærings- og undervisningssituasjon og har en viktig funksjon utover undervisning gjennom kurs og seminarer. Finch (5) intervjuet personer som søkte statistisk veiledning, for å studere dette fra klientenes perspektiv. Han fant at forskerne forventet minst ett av følgende konkrete resultater:

- Kunnskap som gjør forskeren uavhengig og selv i stand til å utføre analyser

- Nødvendig forståelse for hvorfor en statistisk metode er brukt, og hvilke problemer eller begrensinger metoden har

- Svar på et konkret spørsmål

- Raske tilbakemeldinger for å kunne holde tidsfrister og ikke forsinke fremdriften i forskningen

Det var videre forventet at den statistiske konsulenten skulle være en veileder ved valg av statistisk tilnærming. Vedkommende måtte kunne svare på forskningsspørsmål, være en lærer som forklarer hvorfor en prosedyre er riktig og hvordan den fungerer, være god til å analysere data (altså en dyktig «tallknuser») og en kvalitetsmonitor som kan peke på mulige feil eller problemer knyttet til forskningsprosjektet.

Spesialister i statistisk konsultasjon har foreslått å dele inn forskere på grunnlag av deres behov for opplæring og undervisning (6):

- Forskeren har tilstrekkelig kunnskap til å forstå og anvende de statistiske funnene og resultatene fra konsultasjonen. Da er ikke videre opplæring nødvendig

- Forskeren mangler nødvendig kunnskap og er klar over dette. Da er statistisk opplæring en viktig del av konsultasjonen

- Forskeren mangler nødvendig kunnskap, men er ikke klar over dette. Da er både forskningsmetodisk og statistisk opplæring en viktig del av konsultasjonen

\section{Viktige egenskaper}

\section{hos en statistisk konsulent}

Johnson \& Warner (7) undersøkte hvilke faktorer som gjør en statistisk konsultasjon vellykket for den som ber om hjelp. Interessant nok fant de at det statistikere tror er viktigst, kan være noe annet enn det som er viktig for klienten. En faglig optimal analyse av dataene er naturligvis essensielt for en statistiker, men det var ikke alltid det viktigste for klientene. Klientene ønsket svært ofte å få vite hvorfor en metode kan brukes. En meget avansert metodikk var derfor av begrenset interesse fordi forskeren ikke kunne eller var villig til å bruke tid for å forstå metodikken.

Statistisk konsultasjon er en «tverrfaglig øvelse» der man må lære seg å kommunisere med fagfolk fra andre felter på deres språk. Jeg synes Bowman (8) har noen gode refleksjoner omkring forholdet mellom statistikk som eget teoretisk fag og statistikkens praktiske anvendelse innenfor andre fagområder. Han mener at teoretisk statistikk ikke er isolert fra praktisk anvendelse. Et kjent argument i forbindelse med teoretisk grunnleggende forskning er at den senere kan komme til å få en eller annen praktisk anvendelse. Erfaring fra statistisk rådgivning gir ofte et mer nyansert bilde. Bowman (8) mener at faget bør plasseres midt imellom teoretisk teori og praktisk anvendelse. Jeg mener da at tverrfaglighet kan gå i begge retninger, der praktisk anvendelse kan lede til nye statistiske metoder, som igjen kan gi en bedre teoretisk forståelse og dybde.

Statistikere med omfattende erfaring i rådgivning og tverrfaglig arbeid er ofte naturlig flinke til å kommunisere og har en noe pragmatisk holdning til matematisk teori. De skal tilpasse analysen til både den relevante problemstillingen og de faktiske dataene. Det overordnede målet er at analysene skal gi en fornuftig konklusjon på en problemstilling. En anvendt statistisk analyse vil i praksis aldri forekomme uten forhåndskunnskap om problemstillingen og en kritisk medisinsk vurdering av resultatene. En pragmatisk statistiker legger størst vekt på å løse problemer, mindre på underliggende filosofiske og teoretiske betraktninger (9). Jeg mener at det beste resultatet av en vellykket statistisk veiledning er at den bidrar til suksess - det være seg bedre 


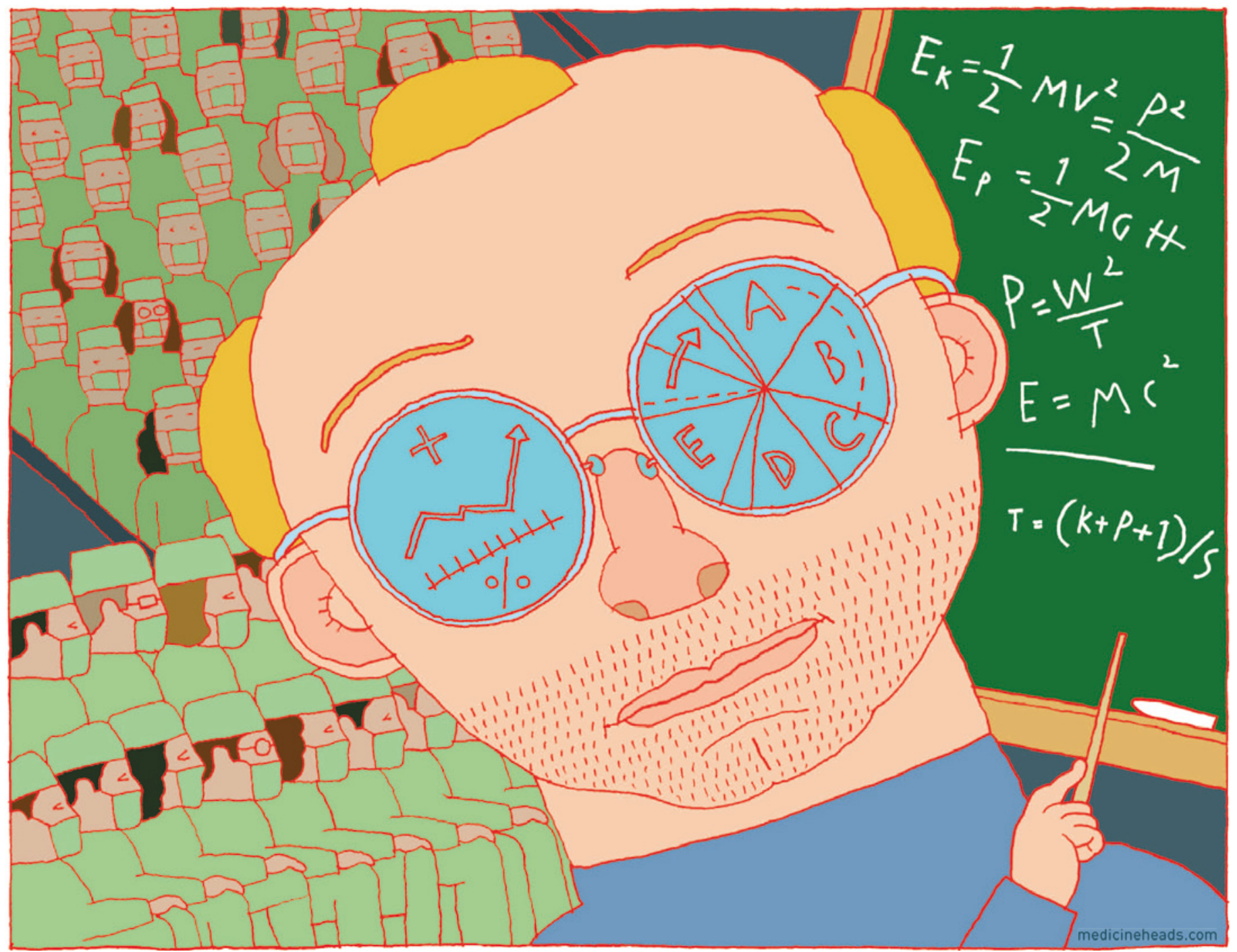

Illustrasjon (c) Trond Nordahl

inntjening $\mathrm{i}$ industri og finans eller flere og bedre forskningspublikasjoner.

\section{Hvordan utdanne \\ statistikere til veiledere?}

Anvendt statistikk har endret seg mye etter at man tok i bruk datamaskiner og avanserte statistiske programmer. Det er sagt at denne utviklingen har medført at statistisk læring har endret seg fra metodiske kalkulasjoner og prosedyrer til statistisk analyse som kunstart (10). Veiledere i forskningsmetodikk og de som arbeider med anvendt statistikk må på en forståelig måte kunne formidle problemløsning til forskere uten matematisk bakgrunn.

Dette involver altså mange aspekter som man ikke nødvendigvis lærer gjennom matematiske og metodebaserte universitetsstudier. Selv om det nå er vanlig at lærebøker inneholder mange eksempler og datasett, er disse ofte forenklet og bedre tilpas- set metodene enn «ekte» forskningsdata. Studenter i statistikk deltar selv sjelden i innsamling av data. Dataene blir som oftest ferdig presentert med en skjematisk beskrivelse av bakgrunn og innsamling. Med begrenset tid til rådighet og et krav om å lære mange matematiske og tekniske metoder er det forståelig at statistikkstudenter ikke kan bruke årevis på selv å samle inn data. Dette kan være en pedagogisk utfordring. Det å samle inn data kan bli betraktet som bortkastet tid, noe som kan bidra til et inntrykk av at statistikeren sitter isolert på sitt kontor, mottar data per e-post og kun gir lyd fra seg når disse er «ferdig analysert» (3).

Janice Derr skriver om sine erfaringer fra Penn State University og om nytten av tverrfaglig samarbeid som en del av statistikkstudentenes utdanning (11). Ifølge Derr er det spesielt lærerikt hvis studentene selv involveres i det praktiske arbeidet med å samle inn data. Det er god forberedelse til rådgivende arbeid. Jeg mener at studenter som viser talent for å arbeide og kommunisere med andre mennesker og faggrupper, formulere og løse praktiske problemer, og som har evne til å tilpasse enkle metoder for å løse et konkret problem, kan være spesielt godt egnet til å arbeide med statistisk rådgivning.

\section{Finansiering og organisering}

Medisinsk eller juridisk konsultasjon forutsetter betaling og finansiering, det samme gjelder for statistisk konsultasjon. Det å være medforfatter skal alltid innebære et forskningsmessig bidrag, men medforfatterskap som sådant er ikke betaling. Thomas A. Louis, professor i biostatistikk ved Johns Hopkins Bloomberg School of Public Health, understreker i sin artikkel om kompensasjon for statistisk veiledning og rådgivning at det å tilby medforfatter- 
skap som betaling for en tjeneste er å behandle fagpersoner og fagmiljøer som annenrangs (12). Det betyr at det å bruke fagmiljøer i statistikk uten å tilby annen kompensasjon enn medforfatterskap, verken er en god eller en akseptabel løsning. Derfor må forskningsmiljøer som ønsker statistisk rådgivning, enten betale for denne på lik linje med andre konsulentbidrag eller, helst, ansette kompetente personer. De største universitetssykehusene i Norge har derfor egne avdelinger for metodologisk forskningsstøtte med ansatte statistikere og epidemiologer.

\section{Begrensninger i statistisk rådgivning}

Medisinsk etikk styrer hvordan helsepersonell utøver sin medisinske kompetanse og sitt kliniske arbeid. Hva betyr det for statistisk konsultasjon? Da tenker jeg ikke spesifikt på statistisk «manipulering» av data for å kunne vise et på forhånd antatt resultat, det handler mer om faglig troverdighet og akademisk kvalitet. Mer relevant er det å spørre om statistikeren bør unngå visse problemstillinger og oppdrag.

Et interessant illustrerende eksempel er oppdrag på vegne av tobakksindustrien, noe som er meget kontroversielt for helsepersonell. David B. Rubin er en meget anerkjent statistiker ved Harvard University. Han har også utført konsulentoppdrag for den amerikanske tobakksindustrien og mener dette er forsvarlig når det utøves $i$ en akademisk kontekst (13). Hans oppdrag for tobakksindustrien var å analysere effekten av at den ikke informerte om helsefaren, $i k k e$ å motbevise at røyking i seg selv er meget helseskadelig. Rubin mente at påtalemyndighetene ikke brukte gode nok statistiske metoder. Et viktig poeng for ham var at beslutninger må bygge på gode statistiske analyser, og at man ikke kan bruke dårlige statistiske analyser med utdaterte metoder som bevis hvis man ønsker å få noen dømt (13).

Som fag har statistikk og forsøksmetodikk en iboende objektivitet og nøkternhet. Det er derfor viktig at det også innen helsefaglig problematisk tematikk er tilbud om adekvat statistisk analyse. Det er rimelig å tenke seg at det er enklere for statistiske rådgivere å gå inn i betente og kontroversielle problemstillinger enn det er for andre helsefaglige forskere.

\section{Statistikkens fremtid i medisinen}

Det er nå nesten utenkelig at en medisinsk forskningsartikkel er uten p-verdier, og kravene om avanserte metoder øker stadig. Akkurat som medisinsk behandling må vurderes ut fra kostnad og nytte, må avanserte statistiske metoder vise at de faktisk gjør medisinsk forskning bedre og til slutt kommer pasientene til gode.

Det er vanskelig å forutse utviklingen innenfor medisin og helsevesen i nærmeste fremtid. Men i et tusenårsperspektiv er Star Trek en populær fremtidsvisjon. Her er stetoskop, skalpell og åpen kirurgi erstattet med dataskjermer, sensorer og datastyrte operasjonssaler. Det lover godt for statistikkens og dataanalysens fremtidige rolle i medisinsk forskning.

\section{Are Hugo Pripp (f. 1971)}

er professorkompetent forsker. Han arbeider ved Avdeling for biostatistikk, epidemiologi og helseøkonomi, Oslo universitetssykehus. Forfatter har fylt ut ICMJE-skjemaet og oppgir ingen interessekonflikter.
Litteratur

1. Altman DG. Statistics and ethics in medical research. VIII-Improving the quality of statistics in medical journals. Br Med J (Clin Res Ed) 1981; 282: $44-7$.

2. Ritter C. Seeking useful contribution. AStA - Adv Stat Anal 2007: 91: 407-11.

3. Kenett R, Thyregod P. Aspects of statistical consulting not taught by academia. Stat Neerl 2006; 60: $396-411$

4. Kauermann G, Weihs C. Statistical consulting. AStA - Adv Stat Anal 2007: 91:343-47.

5. Finch $\mathrm{H}$. Client expectations in a university statistical consulting lab. American Statistical Association: The Statistical Consultant 1999; 16: 5-9.

6. Deutsch R, Hurwitz S, Janosky J et al. The role of education in biostatistical consulting. Stat Med 2007: 26: 709-20.

7. Johnson HD, Warner DA. Factors relating to the degree of which statistical consulting clients deem their consulting experiences to be a success. Am Stat 2004: 58: 280-9.

8. Bowman AW. Interdisciplinary research: the importance of learning other people's language. AStA - Adv Stat Anal 2007; 91: 361-365.

9. Chatfield C. Confessions of a pragmatic statistican. J Roy Stat Soc D - Sta 2002; 51: 1-20.

10. Pfannkuch M, Wild CJ. Statistical thinking and statistical practice: themes gleaned from professional statisticians. Stat Sci 2000; 15: 132-52.

11. Derr J. Statistical consulting in university setting: Don't forget the students. Chance 2008; $21: 38-39$.

12. Louis TA. Compensation for statistical consulting services: observations and recommendations. Chance 2008: 21: 36-7.

13. Rubin DB. The ethics of consulting for the tobacco industry. Stat Methods Med Res 2002; 11: 373-80.

Mottatt 10.5. 2013, første revisjon innsendt 19.6 2013, godkjent 1.7. 2013. Redaktør Merete Kile Holtermann. 